\title{
IRINA SEDAKOVA 65. A LIFE DEDICATED TO THE LIFE-GIVING WORD
}

Irina Sedakova is one of the brightest names among the representatives of the modern Moscow Ethnolinguistics School. She is a Balkanist, Slavist, educator, publicist, translator and publisher. The researcher is a distinguished specialist in the field of ethnolinguistics, sociolinguistics and folkloristics. She is an author of nearly 400 works published in 32 countries. The area of her scientific interests is extremely large, covering both the traditional culture and the most recent problems of modernity (the language of the media, Internet and advertising, semiotics of the Moscow protest actions). She attracts a wide interest among both scholars and inquisitive readers working in the various fields of humanities. She is not only a researcher, but also an "activist" of the word - an organizer of international scientific events related to the study of language and culture.

A scientist of Irina Sedakova's level hardly needs to be presented, but we will still briefly mention some aspects of her scientific biography.

Irina Sedakova graduated from the Moscow State University in 1978 with a degree in "Slavic Languages". This is where she met teachers like Associate Professor

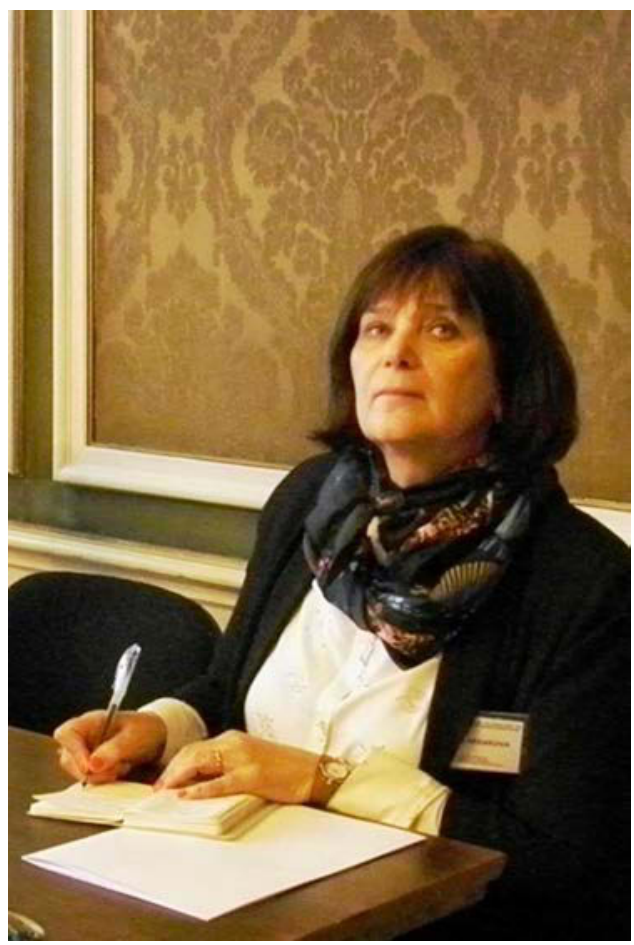


Nadezhda Kotova and the Professors Miroslav Yanakiev and Todov Boyadzhiev. These scholars become an example and benchmark for her, and therefore she retains a deep gratitude towards them. Thus, after N. Kotova's death, she published the monumental work by her teacher, handed over to her as a manuscript (N.V. Kotova. "The Language of Albanians in the Ukraine in the middle of XX ${ }^{\text {th }}$ century”. M., 2017 - in Russian).

In 1984 she defended her candidate dissertation at the same university, dedicated on the "Vocabulary and symbolism of Bulgarian Christmas - Newyear rituals" under the supervision of the academician Nikita Ilich Tolstoy. In 2007 she defended her doctoral thesis at the Institute of Slavic Studies - RAS on the topic "Lingua-cultural bases of the Bulgarian traditional childbirth's text". Between 1983 and 1991 she taught Bulgarian language in the Department of Slavic Philology at the Moscow. From 1991 until present she works at the Institute of Slavic Studies at RA State University, while between 2010 and 2015 she was teaching ethnolinguistics and intercultural communications at the Russian State University of Humanities as well. Irina Sedakova has, moreover, held lecture courses abroad: at the University of Exeter in the UK between 1994 and 1996 and at Sassari University (Sardinia, Italy) in November 2010, she also gave talks in Germany, Japan, Belgium, etc.

At present Irina Aleksandrovna Sedakova holds the degree DrSc in Philology, she is a leading researcher, Head of the Department of Typology and Comparative Language Studies and BALCANICA center for lingua-cultural studies at the Institute of Slavic Studies at the Russian Academy of Sciences.

Furthermore, Irina Sedakova is one of the most active participants in the process of internationalization of science and getting the researchers who share common interests together. This ambitious and demanding work consists of the creation and organization of significant scientific events, important for the cohesion of the global research field. She is the co-chair of the Working Group "The Ritual Year" at SIEF (International Society for Ethnology and Folklore), Scientific Secretary of the Russian Committee at the International Association for the Study of the South-East European Countries (AIESEE), Chairman of the Organizing Committee of regularly held international meetings "Balkan Studies" (Balkanskie chtenia), and Editor-in-Chief of the eponymous series at the Institute of Slavic Studies, RAS. Thanks to this activity, a number of scientists from the Balkan and Baltic countries (among whom is the author of these lines) are involved in a representative academic space expanding the 
horizon of research, discussions and joint publications. As a result, we have above 30 collections based on wide international cooperation, achieved due to her active editorial involvement.

Irina Sedakova's research activity is impressive. It builds on field studies in Bulgaria and other Balkan and Slavic countries as well as participation in the preparation and issuance of fundamental projects such as "Maly dialektologicheskiy atlas Balkanskih yazykov" (Small Dialectal Atlas of Balkan Languages (MDABYA), Andrey N. Sobolev's project); "Slavic Antiquities. Ethnolinguistic Dictionary" (Vol. 1-5, 1995-2012, under the general editorship of N.I. Tolstoy, where she is among the authors), and an author, compiler and editor of a number of collections, published by the Institute of Slavic Studies.

The basis for this multilateral activity is her research on the Balkan Languages and Ethnocultural Union, understood as a structural, typological and mental proximity/identity of a number of linguistic and cultural facts in the diverse linguistically and culturaly Balkans. The specific linguistic and ethnocultural Balkan symbiosis (the so-called Balkanisms) is inherent not only in the traditional, but also in the modern culture of the peoples of SouthEastern Europe (see, for example, I. Sedakova's research on the post-socialist Slavic-Balkan language union). The Balkanisms are a consequence of historical circumstances - the similar past and geographical proximity of the Balkan peoples determine the peculiarity and dynamics of the linguistic and cultural processes for centuries. They foreground, moreover, the existence of common cultural (folk-cultural) terms, phraseologisms, verbal formulas and clichés, i.e. linguistic facts reflecting common mythological concepts, rituality, beliefs, etc., a common (linguistic and cultural) model of the world (according to the terminology of T.V. Tsivyan).

One of the most important studies of Irina Sedakova, summarizing her scientific ideas, is her monograph "Balkanskie motivy v yazyke i kul'ture bolgar. Rodinny text" (Balkan Patterns in the Language and Culture of the Bulgarians. Childbirth Text), Moscow 2007, also published in Bulgarian in 2013. The book explores the birth texts, based on the concept of the "fate" and the interrelationships between a term and its meaning and cultural allusions. Her methodological approach is based on the study of the ethnolinguistical connotations, the linguistic realization (vocabulary and phraseology), beliefs, rituals and magic acts. In this way, these phenomena are seen as a cultural text (following V.N. Toporov). A cultural text is a semiotic phenomenon, manifested 
at different systematic levels in the structure of culture - lexical, idiomatic, folklore, ethnographic, etc. Focused on the Bulgarian traditional culture (including original fieldwork materials), the book includes wide Balkan comparative materials, historical references (antique, Paleo-Balkan, Ottoman, Byzantine, Turkish, etc.) reflecting the common topoi (linguistic and ethnocultural) and their formation in the Balkan cultures.

In the recent years I. Sedakova is investigating the values (axiology) in the Slavic lingual cultures and concepts such as "family", "old age", "love", etc. in the context of the importance and dynamics of their development in the framework of "tradition - modernity" binary. Irina Sedakova continues to attract new authors from different Slavic countries to cooperation and to her investigation of the discussed topic in particular, aiming to achieve maximal precision and completeness of research.

In the framework of this short review it seems impossible to outline the entire diversity of research, activities and academic achievements of Irina Sedakova. Perhaps the most important for me is to recommend that the readers get acquainted with her creative work, because it stimulates new thoughts and research ideas. Finally, I pass on my sincere wishes to Irina for health, happiness and success, both professionally and personally!

\section{References}

Agapkina, Tatiyana (ed.) 2020. Slavyanskaia etnolingvistika. Moskva: Institut slaviyanovedeniia, pp. 145-160. Available at https://inslav.ru/slavyanskayaetnolingvistika-bibliografiya-m-2020, last accessed on 26.10.2020.

Anastasova, Ekaterina 2007. Irina A. Sedakova. Balakanskie motivy v yazyke i kul'ture bolgar. Rodinny tekst [Irina A. Sedakova. Balkan Patterns in the Language and Culture of the Bulgarians. Childbirth Text]. Balgarski folklore, No. 3. (In Bulgarian.) Sofia, pp. 152-154.

Gurska, Olga 2020. Prof. Irina Sedakova: "Balgarite vse poveche se vrashtat kam korenite si" [Prof. Irina Seadakova: Bulgarians are increasingly returning to their roots]. Rossia segodnia/Rusia dnes, No. 27 (1105), XXXIII, July 3-9. (In Bulgarian.)

Sedakova, Irina Aleksandrovna 2007. Balkanskie motivy v yazyke i kul'ture bolgar. Rodinny tekst [Balkan Patterns in the Language and Culture of the Bulgarians. Childbirth Text]. (In Russian.) Moskva: Indrik. 
Sedakova, Irina 2013. Balkanski motiovi v ezika i kulturata na balgarite. Razhdane $i$ sadba [Balkan Patterns in the Language and Culture of the Bulgarians. Birth and Destiny]. (In Bulgarian.) Sofia: BAN.

\section{Internet Sources}

https://inslav.ru/nauchnye-podrazdeleniya/otdel-tipologii-i-sravnitelnogoyazykoznaniya

https://inslav.ru/nauchnye-podrazdeleniya/centr-lingvokulturnyh-issledovaniybalcanica

Ekaterina Anastasova

Ekaterina Anastasova, PhD, Associate Professor, Head of the Department of Comparative Folklore Studies, Institute of Ethnology and Folklore Studies with Ethnographic Museum at the Bulgarian Academy of Sciences, Sofia. She is an ethnolinguist and folklorist, working in the field of social and cultural development of the contemporary society. Her research explores the problems of ethnicity, religiosity and nationalism in the post-socialist space. 